\title{
STRUCTURE AND THERMAL PROPERTIES OF LIGNINS: CHARACTERIZATION BY INFRARED SPECTROSCOPY AND DIFFERENTIAL SCANNING CALORIMETRY
}

\author{
JUSTO LISPERGUER ${ }^{\prime *}$, PATRICIO PEREZ ${ }^{2}$, SILVIO URIZAR ${ }^{l}$ \\ 'Departamento de Química, Facultad de Ciencias. Universidad del Bío-Bío.Avda. Collao 1202, Concepción, Chile. \\ ${ }^{2}$ Departamento de Ingeniería en Maderas, Facultad de Ingeniería. Universidad del Bío-Bío, Avda. Collao 1202, Concepción, Chile.
}

(Received: April 14, 2009 - Accepted: July 23, 2009)

\begin{abstract}
After cellulose, lignin is, the second most abundant component in wood. In the pulping industry, the introduction of modern Kraft pulping technologies could produce chemical modification in lignin's functional groups.

Kraft lignins from Eucaliptus nitens and Pinus radiata industrial black liquors were isolated by acid precipitation. An organosolv lignin was obtained from spent liquor from the P.radiata wood pulping process.

All lignins were acetylated with acetic anhydride and characterized by Fourier-transformed infrared spectroscopy (FT-IR) .

Analysis based on the IR-fingerprint spectral region indicates several differences in the functional groups of the different types of lignins.

The thermal behaviour of unmodified and acetylated lignins were studied by differential scanning calorimetry (DSC) and the glass transition temperatures (Tg) were determined and compared with values reported in the literature.

The acetylated lignins show a decrease in the Tg values which is probably due, to the at plasticization effect of the acetylation reaction.
\end{abstract}

Keywords : lignins, infrared spectroscopy, glass transition temperatures.

\section{INTRODUCTION}

Lignin is a phenolic polymer present in large amounts in plants celss and wood tissues. It is the second most abundant natural polymer after cellulose.

This macromolecule is complex and it is widely accepted that the biosynthesis of lignin stems from the polymerization of three types of phenylpropane units, also referred to as monolignols. ${ }^{1,2,3,4}$ These units are coniferyl, sinapyl and p-coumaryl alcohol. The three structures are depicted in Figure 1.

Coniferyl alcohol/guaiacyl: $\mathrm{R}^{\prime}=\mathrm{OMe}, \mathrm{R}^{\prime \prime}=\mathrm{H}$

Sinapyl alcohol/syringyl: $\mathrm{R}^{\prime}=\mathrm{R}^{\prime \prime}=\mathrm{OMe}$

p-Coumaryl alcohol : $\quad \mathrm{R}^{\prime}=\mathrm{R}^{\prime \prime}=\mathrm{H}$

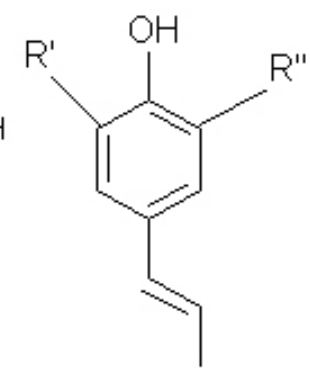

Fig. 1. Units of monolignoles presents in lignins

The main source for technical lignins is the black liquor from the pulping process. ${ }^{5,6}$ In the pulping industry, vast amounts of lignin are separated from wood and then, burned internally in the pulp mill to produce steam and electricity, except for those produced for specialty chemical purposes. ${ }^{7}$

In terms of global industrial lignin production, the Kraft pulping process is the principal process.

Numerous studies have been conducted over the past two decades to elucidate the chemical structure of Kraft lignins using different techniques. The most important ones used are : nuclear magnetic resonance (NMR) ${ }^{8,9,10}$, infrared spectroscopy ( IR $)^{11,12}$, ultraviolet spectroscopy (UV) ${ }^{13}$, chemical and functional characterization ${ }^{14,15}$, pyrolysis-gas chromatograpgy ${ }^{16}$ and others.

The use of Fourier-transform infrared spectroscopy (FT-IR) to determine the functional groups in lignin is well described in the literature. Hergert ${ }^{17}$, Faix $^{18}$, Schultz and Glasser ${ }^{19}$ and more recently Chipanina et al ${ }^{20}$, described qualitatively the occurrence of carbonyl $(\mathrm{C}=\mathrm{O})$ groups, aromatic structures, $\mathrm{C}_{\text {aliph }}-\mathrm{O}$ and $\mathrm{C}_{\text {arom }}-\mathrm{O}$ bonds and also the substitution pattern in the benzene ring.

New delignification processes based on organic solvents or the changes introduced with the modern Kraft pulping technologies could produce chemical modification in lignin's functional groups. These changes in the chemical structure have an important influence on lignin's physical and thermal properties.

The introduction of new higher resolution FT-IR equipments to study lignocellulosic materials ${ }^{21,22}$ and the utilization of non-conventional wood species such as Eucaliptus nitens in the Kraft pulping process have created the possibility to carry out the present study.

The aim of this work was use FT-IR to study the principal functional groups of Pinus radiata and Eucaliptus nitens lignins in Kraft black liquors in order to compare them with an organosolv lignin. Also, we report the thermal behaviour of these non-acetylated and acetylated lignins in order to study the influence of the acetylation reaction on the glass transition temperature (Tg) of lignin to utilize its as plastic antioxidants in future studies.

\section{EXPERIMENTAL}

Eucaliptus nitens and Pinus radiata black liquors of the Kraft pulping process were supplied by CMPC Industry ( Nacimiento-Chile) and Arauco Industry ( Arauco-Chile), respectively.

The organosolv lignin was obtained from the spent liquor of the P.radiata wood pulping process with a formic acid - acetone mixture. The pulping conditions were:

Wood/liquor ratio: 1g / 6mL. Formic acid / acetone : $70 / 30$ v/v. Pulping time: 23 minutes. Temperature of cooking: $165^{\circ} \mathrm{C}$

The pulping was performed in the Renewable Resources Laboratory ( Universidad de Concepción) $^{23}$.

The Kraft black liquors were initially filtered through a Whatman $\mathrm{N}^{\circ} 4$ filter paper and then the $\mathrm{pH}$ and solid content were determined.

The liquors were concentrated at $28-30 \%$ solid content in a rotary evaporator at $70^{\circ} \mathrm{C}$.

The liquors were then neutralized with $2 \mathrm{M} \mathrm{H}_{2} \mathrm{SO}_{4}$ to $\mathrm{pH}$ 7.0, stirred for 1 hour and then further acidified to $\mathrm{pH} 3.0$. At this $\mathrm{pH}$ lignin precipitates and two phases are obtained. The lignin was stirred for 30 minutes and then filtered and washed several times with $1 \mathrm{M} \mathrm{HCl}$ to eliminate salts and some carbohydrates. hours.

The isolated solid lignins were dried in a drying oven at $70^{\circ} \mathrm{C}$ for 12

\section{Acetylation}

The acetylation reaction of the different lignins was carried out using a method similar to the one used for wood flour. ${ }^{24}$

The method is the following : $2 \mathrm{~g}$ dry lignin was placed in a $300 \mathrm{~mL}$ flat bottom flask and $100 \mathrm{~mL}$ of acetic anhydride was added. The flask was 
dipped into an oil bath set at $120^{\circ} \mathrm{C}$ and fitted with a reflux condenser. Once the reaction of 1 hour was completed, the flask was removed from the oil bath and the lignin was filtered.

The acetylated lignin was oven dried at $70^{\circ} \mathrm{C}$ for 16 hours and then weighed.

\section{FT-IR spectroscopy}

The FT-IR analysis of unmodified and acetylated lignins were recorded on a Nicolet model Nexus spectrophotometer, using $\mathrm{KBr}$ pellets containing $1 \%$ finely ground samples.

DSC analyses

The thermal analysis of unmodified and acetylated lignins was carried out by means of a METTLER TOLEDO differential scanning calorimeter ( DSC $822^{\mathrm{e}}$ ) equipped with a thermal analysis data STAR ${ }^{\mathrm{e}}$ software system.

All the results of differential scanning calorimetry represent the average of at least five determinations. Samples of about $5-10 \mathrm{mg}$ were run at a heating rate of $10^{\circ} \mathrm{C} / \mathrm{min}$ under nitrogen atmosphere between $30^{\circ} \mathrm{C}$ and $150^{\circ} \mathrm{C}$ to remove previous thermal history.

For Tg determinations, a heating rate of $20^{\circ} \mathrm{C} / \mathrm{min}$ was used, because the glass transition is more pronounced at faster heating rates. ${ }^{25}$

\section{RESULTS AND DISCUSSION}

Table 1 shows the solid content and $\mathrm{pH}$ of $\mathrm{E}$. nitens and $\mathrm{P}$. radiata industrial black liquors.

Table 1. Physical properties of industrial Kraft liquors.

\begin{tabular}{|c|c|c|}
\hline Kraft liquor & Solid content (\%) & $\mathrm{pH}$ \\
\hline E. nitens & 14 & 10.5 \\
\hline P. radiata & 18 & 11.5 \\
\hline
\end{tabular}

Table 2 describes the lignin yield, where a very similar lignin yield for $\mathrm{E}$. nitens and P.radiata Kraft black liquors is observed after the precipitation and washing process. The low ash content indicates the high purity levels in the lignin obtained in the process.

Table 2 . Recuperation of Kraft lignins from industrial liquors.

\begin{tabular}{|l|c|c|c|c|c|}
\hline Kraft lignin & $\begin{array}{c}\text { Solid } \\
\text { content } \\
(\%)\end{array}$ & $\begin{array}{c}\text { Total solids } \\
\text { acidified } \\
(\mathrm{g})\end{array}$ & $\begin{array}{c}\text { Total } \\
\text { lignin } \\
\text { mass } \\
(\mathrm{g})\end{array}$ & $\begin{array}{c}\text { Recuperation } \\
(\%)\end{array}$ & $\begin{array}{c}\text { Ash } \\
\text { content } \\
(\%)\end{array}$ \\
\hline $\begin{array}{l}\text { Kraft } \\
\text { eucalipto }\end{array}$ & 28 & 148 & 48 & 32.4 & 0.65 \\
\hline Kraft pino & 30 & 242 & 80 & 33.0 & 0.55 \\
\hline
\end{tabular}

FT-IR characterization of lignins found.

Table 3 presents the wavenumbers and the important band identifications
Table 3. Bands assignments of the non-acetylated lignins

\begin{tabular}{|c|c|c|c|c|}
\hline Lignin & \multicolumn{4}{|c|}{ Peak wavenumber $\left(\mathrm{cm}^{-1}\right)$} \\
\hline \multirow{10}{*}{$\begin{array}{l}\text { Unmodified } \\
\text { lignin }\end{array}$} & K.pino & K.eucalipto & Organosolv & Band assignment \\
\hline & 3414 & 3423 & 3423 & $\begin{array}{l}\text { Stretching vibrations } \\
\text { in } \mathrm{O}-\mathrm{H}\end{array}$ \\
\hline & 2935 & 2928 & 2937 & $\mathrm{CH}$ stretching vibrations \\
\hline & - & 2851 & - & Tertiary CH groups \\
\hline & 1714 & 1715 & 1712 & Unconjugated carbonyls \\
\hline & 1598 & 1603 & 1603 & Aromatic stretching band \\
\hline & 1509 & 1510 & 1506 & Aromatic ring \\
\hline & 1458 & 1459 & 1457 & $\mathrm{C}-\mathrm{H}$ deformation \\
\hline & - & 1328 & - & Bending vibrations of $\mathrm{OH}$ \\
\hline & 1269 & 1219 & 1269 & C-O stretching \\
\hline \multirow{3}{*}{ (methoxyls) } & 1215 & 1117 & 1212 & $\begin{array}{l}\text { C-O stretching (phenolic } \\
\text { hydroxyl groups) }\end{array}$ \\
\hline & 1031 & 1036 & 1032 & $\begin{array}{l}\text { C-O deformation } \\
\text { (mehtoxyl groups) }\end{array}$ \\
\hline & 857 & 836 & 867 & $\begin{array}{l}\text { C-H out- of -plane } \\
\text { deformation }\end{array}$ \\
\hline
\end{tabular}

Table 4. Bands assignments of the acetylated lignins.

\begin{tabular}{|c|c|c|c|c|}
\hline Lignin & Peak w & avenumber $(\mathrm{c}$ & $\mathrm{m}^{-1)}$ & \\
\hline Acetylated & K.pino & K.eucalipto & Organosolv & Band assignment \\
\hline & 3459 & 3460 & 3452 & $\begin{array}{l}\text { Stretching vibrations } \\
\text { in } \mathrm{O}-\mathrm{H}\end{array}$ \\
\hline & 2940 & 2934 & 2941 & $\mathrm{CH}$ stretching vibrations \\
\hline & 2838 & 2849 & 2843 & Tertiary $\mathrm{CH}$ groups \\
\hline & 1762 & 1757 & 1755 & Unconjugated carbonyls \\
\hline & 1597 & 1599 & 1602 & Aromatic stretching band \\
\hline & 1505 & 1504 & 1504 & Aromatic ring \\
\hline & 1460 & 1461 & 1458 & $\mathrm{C}-\mathrm{H}$ deformation \\
\hline & 1370 & 1370 & 1369 & $\begin{array}{l}\text { Bending vibrations of } \mathrm{OH} \\
\text { bonds }\end{array}$ \\
\hline & 1199 & 1213 & 1202 & $\begin{array}{l}\text { C-O stretching, aromatic } \\
\text { (phenyl) }\end{array}$ \\
\hline & - & 1127 & - & Dialkyl ether linkages \\
\hline & 1033 & 1038 & 1033 & $\begin{array}{l}\text { C-O deformation } \\
\text { (methoxyl group) }\end{array}$ \\
\hline & 902 & 903 & 904 & $\begin{array}{l}\mathrm{C}-\mathrm{H} \text { out -of- plane } \\
\text { deformation in } \\
\text { ethylenic double bonds }\end{array}$ \\
\hline & - & 834 & - & $\begin{array}{l}\text { Trisubstituted aromatic } \\
\text { ring }\end{array}$ \\
\hline
\end{tabular}

Fig. 2 shows the infrared spectra of the three unmodified lignins. Below we present an analysis of the recorded spectra of the lignin used in this study, based on assignments given by $\mathrm{Faix}^{26}$, and Boeriu ${ }^{11}$.

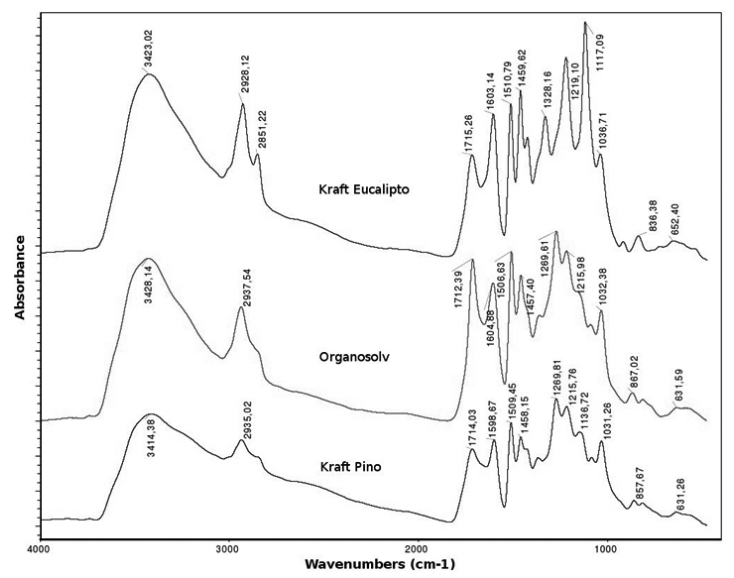

Figure 2. FT-IR spectra of non-acetylated lignins 
All lignins show a broad band between $3400-3500 \mathrm{~cm}^{-1}$ with similar peaks for E. nitens and organosolv lignins $\left(3423 \mathrm{~cm}^{-1}\right)$ and something different for P. radiata lignin $\left(3414 \mathrm{~cm}^{-1}\right)$. These strong bands are attributed to the hydroxyl groups in phenolic and aliphatic structures. The bands centred around 2928 and $2937 \mathrm{~cm}^{-1}$, predominantly arising from $\mathrm{CH}$ stretching in aromatic methoxyl groups and in methyl and methylene groups of side chains.

The spectral region below $2000 \mathrm{~cm}^{-1}$ is more difficult to analyse, since most bands are complex, with contribution from various vibration modes.

In the carbonyl region, weak to medium bands are found at 1712-1715 $\mathrm{cm}^{-1}$ that can be associated to unconjugated $\mathrm{C}=\mathrm{O}$, and conjugated carbonyl/ carboxyl spectra at $1598-1603 \mathrm{~cm}^{-1}$.

Aromatic ring bands and C-H deformation between 1506 and $1457 \mathrm{~cm}^{-1}$ are very similar for all lignin but the bending vibration of $\mathrm{OH}$ at $1328 \mathrm{~cm}^{-1}$ is only visible in E.nitens lignin. This band has been reported for syringyl ring of hardwood and non-wood lignins ${ }^{11}$.

C-O stretching for methoxyl groups show similar bands in P.radiata and organosolv lignins $\left(1269 \mathrm{~cm}^{-1}\right)$ although it is weaker in E.nitens at $1219 \mathrm{~cm}^{-1}$.

Differences were also observed for the phenolic hydroxyl groups. The absorbance in E. nitens is a strong band at $1117 \mathrm{~cm}^{-1}$ while P.radiata and organosolv lignin show a less intense band at $1212-1215 \mathrm{~cm}^{-1}$.

The spectral region at $1031-1036 \mathrm{~cm}^{-1}$ and below these wavenumbers, show similar weak bands for the three lignins originating from aromating $\mathrm{C}-\mathrm{H}$ deformation and C-H out -of- plane vibrations, respectively.

Infrared spectra of the acetylated lignin samples were compared to spectra of original samples to establish the extent of esterification reactions and the influence on thermal properties.

Esterification reactions resulted in the drastic reduction of the $\mathrm{OH}$ absorption band between 3400 and $3500 \mathrm{~cm}^{-1}$, as shown in Fig. 3, along with the appearance of the main absorption bands 1750 and 1760 ( $\mathrm{C}=\mathrm{O}$ stretch).

An other absorption band appears for E.nitens lignin at $1127 \mathrm{~cm}^{-1}$ probably due to syringyl ring .

Acetylated lignins are shown in Fig. 3

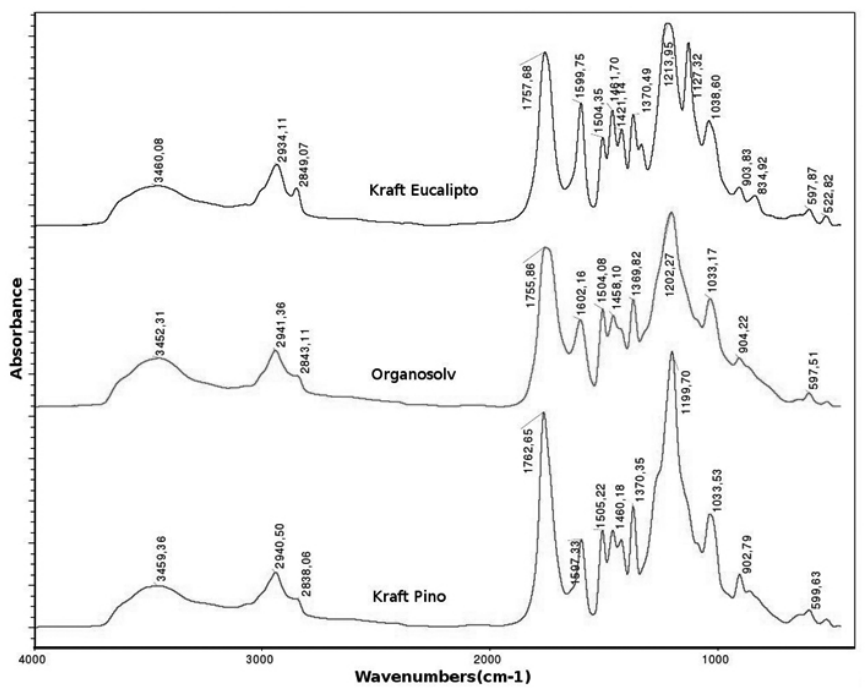

Figure 3. FT-IR of acetylated lignins.

Thermal properties of lignins

DSC is the most widely accepted method for determining glass transition temperature of lignin or modified lignin samples ${ }^{27}$.

The Tg of dry lignin is often more difficult to detect than in a synthetic polymer, due the complex structure of lignin and sometimes only is possible to detect the range of the change in the curve $\mathrm{e}^{28}$.

Figure 4 shows the DSC thermograms of unmodified lignins of E. nitens Kraft liquor, P.radiata Kraft liquor and organosolv lignin .

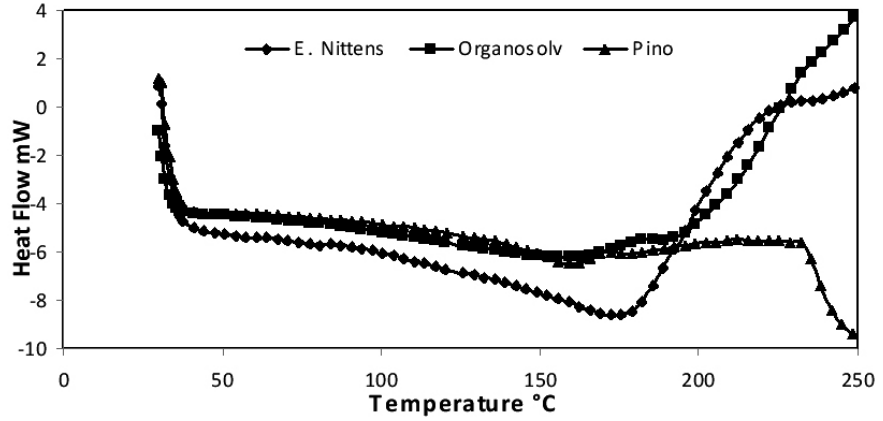

Figure 4. DSC thermograms of unmodified lignins.

The $\mathrm{Tg}$ of the three lignins do not exhibit significant differences, until $170^{\circ}$ $\mathrm{C}$ and were determined from the change in the heating curve, previous to the degradation temperature.

The change in the curve for P.radiata lignin begins above $120^{\circ} \mathrm{C}$, and at $100^{\circ} \mathrm{C}$ for acetylated lignin,(figure 5 ).

For E.nitens lignin, the change begins at $140^{\circ} \mathrm{C}$. Acetylated lignin in the figure 5 shows a change at $120^{\circ} \mathrm{C}$

Figure 5 shows the glass transitions of partially acetylated lignins.

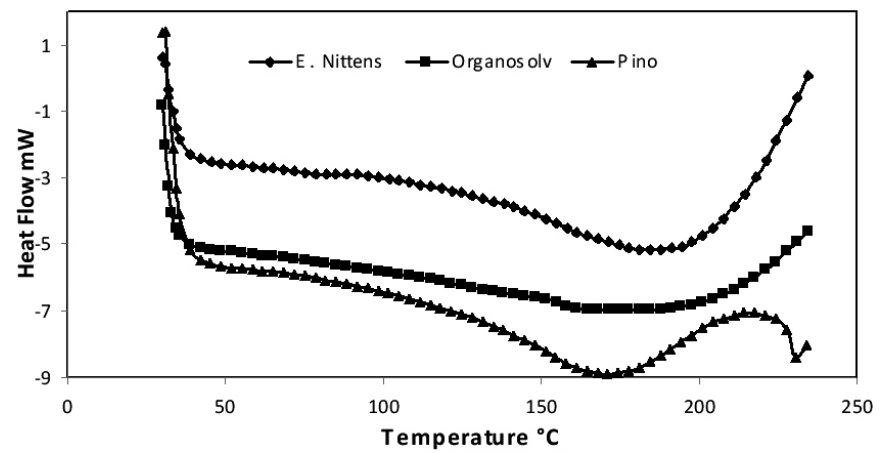

Figure 5. DSC thermograms of acetylated lignins.

Acetylated organosolv lignin shows a weak change of $\mathrm{Tg}$ at $122^{\circ} \mathrm{C}$. In the non-acetylated organosolv lignin a clear change in the curve was not detected.

The $\mathrm{Tg}$ values are in the glass transition region reported in the literature for several types of lignins, between $110^{\circ} \mathrm{C}-150^{\circ} \mathrm{C} . .^{29,30}$.

In Figure 5 the glass transition temperature for all the lignin acetates clearly decreases with respect to the unmodified lignins.

The acetylation reaction produces a plastification phenomenon in the lignin because a decrease in the intermolecular interactions between hydroxyl groups of lignin is observed and lower $\mathrm{Tg}$ values are obtained.

\section{CONCLUSIONS}

FT-IR analysis showed some differences between the spectra for the three lignins studied.

In E. nitens lignin the bending vibration of $\mathrm{OH}$ at $1328 \mathrm{~cm}^{-1}$, can be attributed to the syringyl of hardwood and also the band at $2851 \mathrm{~cm}^{-1}$ attributed to tertiary groups are only visible in E.nitens lignin. These IR bands can be used as a fast technique to characterize this kind of lignin.

P.radiata lignin and organosolv lignin show a strong band at $1269 \mathrm{~cm}^{-1}$ which is attributed to CO stretching. This band is weaker in E. nitens lignin.

Differences were also observed for the phenolic hydroxyl groups. While the absorbance in E.nitens is a strong band at $1117 \mathrm{~cm}^{-1}$ a less intense band at $1212-1215 \mathrm{~cm}^{-1}$ is observed to P.radiata and organosolv lignins.

Acetylated lignins show an important decrease in the band at 3400-3500 $\mathrm{cm}^{-1}$ attributed to $\mathrm{OH}$, while the band of $\mathrm{CO}$ stretches at $1750-1760 \mathrm{~cm}^{-1}$ increasing significantly.

Other absorption bands appear in acetylated lignins at $1370 \mathrm{~cm}^{-1}$ attributed to aliphatic $\mathrm{C}-\mathrm{C}$ stretch probably from acetic anhydride incorporated to the 
lignin molecule in the esterification reactions.

Lignin molecules are composed of phenyl propane units interconnected by about 10 different linkages in a complex matrix that are quite different from most synthetic polymers because of the high degree of association between their macromolecules. Due this, thermal behaviour and glass transitions were often difficult to detect especially in the case of non-acetylated lignins.

Glass transitions for non-acetylated organosolv lignin were indiscernible.

The Tg for the lignins is not easily detected by DSC and a faster heating rate is required to appreciate the weak change in the curve of the thermogram.

The thermal study of the lignins showed a similar behaviour for the glass transition temperature in the three types of lignins analyzed.

As has been reported in the literature, polymer plastification decreases the $\mathrm{Tg}$ value. This study shows that the acetylated lignins exhibit lower Tg values possible due, to the reduction in the degree of intermolecular association occurring within the lignin. Lignin esterification decreases the availability of $\mathrm{OH}$ groups in the lignin molecule and the addition of nonreactive acetyl groups can also make the chains stand off from one another, reducing $\mathrm{Tg}$.

\section{ACKNOWLEDGEMENTS}

This work was supported by grants from project $N^{\circ} 0742063 / \mathrm{R}$. Universidad del Bío-Bío and by Advanced Polymer Research Center. CIPACHILE.

\section{REFERENCES}

1. J.P. Casey, Pulpa y Papel. Química y Tecnología. Vol 1, John Wiley \& Sons, Inc. México (1990).

2. E.Adler, Wood Sci. Technol. 14, 241, (1980).

3. F.S.Chakar, A.J. Ragauskas, Ind. Crops Prod. 20,131, (2004).

4. K.V.Sarkanen, C.H. Ludwig, Lignin, Occurrence, Formation, Structure and Reactions. Wiley/ Interscience, New York, (1971).

5. J.Jiang, B.Greenwood, J.Phillips, E.Becker, Appita. 45(1), 19, (1992)

6. C.L.Chen, Int. Fiber Sci.Technol. Series 11, 183, (1991).

7. D.Feldman, D.Manu, J.Appl. Polym.Sci. 66, 1731, (1997).

8. P.M.Froas, A.J.Ragauskas, J.E.Jiang, Holzforschung, 52, 385, (1998).

9. K.Lundquist. Proton $\left(\mathrm{H}^{1}\right)$ NMR Spectroscopy. In : Methods in Lignin Chemistry. Eds. S.Y.Lin and C.W. Dence. Springer Verlag, Berlin, Heidelberg, 1992 ; p. 242.

10. E.A.Capanema, M.Y.Balakshin, J.F. Kadla, J. Agric. Food Chem. 52,1850, (2004).
11. C.G.Boeriu, D.Bravo, R.J.A. Gosselink, J.E.G. van Dam, Ind. Crops Prod. 20, 205, (2004)

12. B. Hurtling, T.Tamminen, E. Kentä, Holzforschung 51 (5), 405, (1997).

13. R.L. Cunningham, R.L. Maloney, TAPPI, 56, 162, (1973).

14. J.J. Stewart, J.F. Kadla, S.D. Mansfield, Holzforschung, 60, 111 (2006).

15. B.Bujanovic, S.A.Ralph, R.S. Reiner, R.H. Atalla, Holzforschung, 61 492, (2007).

16. J.C. del Río, M.Speranza, A.Gutiérrez, M.J.Martínez, A.T. Martínez, J. Anal. Appl. Pyrolysis, 64, 421, (2002).

17. H. Hergert, Infrared Spectra. In : Lignins - Ocurrence, Formation, Structure and Reaction, Eds, K. Sarkanen and C.Lidwig, Wiley Interscience, New York. 1971 p. 267.

18. O.Faix, Holzforschung, 40, 273, (1991).

19. T.P. Schultz, W.G. Glasser, Holzforschung, 40, 38, (1986).

20. N.N. Chipanina, Y.R.Mirskova, S.A.Medvedeva, I.V. Volchatova, V.A.Babkin, The $8^{\text {th }}$ International Symposium on Wood and Pulping Chemistry . Helsinki, Finland, Vol III, pp 73 (1995).

21. J.Freer, J.Ruiz, M.Peredo, J.Rodríguez, J.Baeza, J. Chil. Chem. Soc. 48 (3), 19, (2003).

22. N.T. Abdel-Ghani, M.M. Hefny, G.A.El-Chaghaby, J.Chil. Chem. Soc. 53 (3), 1585, (2008).

23. J.Freer, J.Rodriguez, J.Baeza, N.Duran, S.Urizar, Bol. Soc. Chil.Quim., 44 (2), 199, (1999).

24. J.Lisperguer, C.Droguett, B.Ruf, M.Núñez, J. Chil. Chem. Soc. 52 (1),1073, (2007).

25. American Society for Testing and Materials (ASTM), D 3418-03, Standard Test Method for Transition Temperatures of Polymers By Differential Scanning Calorimetry. ( 2003).

26. O.Faix, Methods in Lignin Chemistry. Springer-Verlag, Berlin-Heidelberg, 1992.

27. W.G.Glasser, ACS Symposium Series $N^{\circ}$ 742. American Chemical Society, Washington,D.C. 216. 2000.

28. C.Fox, Thesis Master of Science, College of Graduate Studies, University of Idaho, USA, 2006. p. 49.

29. A.M.A.Nada, H.A.Yousef, S.E.Gohary, J.Therm.Anal.Cal. 68, 265, (2002).

30. J.Bouajila, P.Dole, C.Joly, A.Limare, J. Appl. Polym. Sci. 102, 1445, (2006). 